\title{
Correction to: Bottom-up effects of irrigation, fertilization and plant resistance on Tuta absoluta: implications for Integrated Pest Management
}

\author{
Peng Han ${ }^{1} \cdot$ Nicolas Desneux ${ }^{2} \cdot$ Christine Becker ${ }^{3} \cdot$ Romain Larbat $^{4} \cdot$ Jacques Le Bot ${ }^{5} \cdot$ Stéphane Adamowicz ${ }^{5}$. \\ Jiang Zhang ${ }^{6} \cdot$ Anne-Violette Lavoir $^{2}$
}

Published online: 18 February 2019

(c) Springer-Verlag GmbH Germany, part of Springer Nature 2019

\section{Correction to: Journal of Pest Science https://doi.org/10.1007/s10340-018-1066-x}

In the original publication of the article, the article type was incorrectly published as "Original Paper". However, the correct article type is "Review Paper".

Publisher's Note Springer Nature remains neutral with regard to jurisdictional claims in published maps and institutional affiliations.

The original article can be found online at https://doi.org/10.1007/ s10340-018-1066-x.

Peng Han

penghan@ms.xjb.ac.cn

1 CAS Key Laboratory of Biogeography and Bioresource in Arid Land, Xinjiang Institute of Ecology and Geography, Chinese Academy of Sciences, Ürümqi 830011, China

2 INRA (French National Institute for Agricultural Research), University Côte d'Azur, CNRS, UMR 1355-7254, 06903 Sophia Antipolis, France

3 Department of Crop Protection, Hochschule Geisenheim University, 65366 Geisenheim, Germany

4 UMR 1121 UL-INRA Agronomie et Environnement, 2 av. de la Forêt de Haye, 54518 Vandoeuvre-lès-Nancy, France

5 UR1115 PSH, INRA, 84000 Avignon, France

6 State Key Laboratory of Biocatalysis and Enzyme Engineering, School of Life Sciences, College of Life Sciences, Hubei University, Wuhan 430062, China 